Many of these are endeavouring to make the greater India languages fit vehicles for the imparting of scientific teaching. For example, the Vangiya Sahitya Parisat, a learned society in Calcutta, has for some fifteen years past been compiling a vocabulary of chemical and botanical terminology in the vernacular. This is a task in which the help of Western scholars is plainly required, lest there should be misunderstandings and overlapping of effort. So is it also in the field of comparative philology, in which native students are apt to ignore the acquisitions of Western scholarship.

Finally, H.M. the King was happily inspired in suggesting that the pupils of the school may hereafter be "teachers of unselfish government and civilised commerce." Scholarship and science should be disinterested, while commerce should be a loyal and friendly exchange to the benefit of both parties to the transaction. It was, once more, time that the great City of London should recognise that a sound and scientific knowledge of Asiatic and African languages, literary and other, is a necessary part of the extension of British influence in lands where our sole object is to improve the social and physical condition of races which have fallen behind our own standard of civilisation.

At the opening of the school the King was accompanied by the Queen and Princess Mary. On arriving at the school their Majesties were received by Lord and Lady Curzon and Sir John Hewett, chairman of the governing body. The opening ceremony took place in the library, where Sir John Hewett, addressing the King, said they took the King's presence as a sign that his Majesty was fully cognisant of the importance to the Empire of the study of Oriental and African languages and civilisations on a scale which Great Britain, alone among great countries of the world interested in the East, had not hitherto regarded as necessary; and they had planned that the school should be at least equal to the Oriental schools in foreign capitals, and adequate to Imperial needs.

The King, in the course of his reply, said: "I am glad to be the patron of the School of Oriental Studies, and it gives me particular gratification to take part to-day in the ceremony of opening this fine building in which the school is henceforth to carry on its work.

"I cannot sufficiently emphasise the wide scope and vast importance of that work. The school will afford fresh opportunities of study to those services which have been the pioneer of progress and the instrument of good government in India and Egypt. It will furnish with a fuller technical equipment the pioneers of commerce and industry who in each successive generation undertake the duty of upholding the honoured fame of British trade in the East. Its work will serve to develop the sympathy which already so happily exists between my subjects and those of my Far Eastern ally, Japan. But more than this is to be looked for from the school.

"If it happily succeeds in imparting to the pupils sent out as teachers of unselfish government and civilised commerce a clearer comprehension of the thoughts and lives of the diverse races of the East, the good effects of that success will extend far beyond the immediate and tangible results. The ancient literature and the art of India are of unique interest in the history of human endeavour. I look to the school to quicken public interest in the intellectual tradition of that great continent and to promote and assist the labours of the students in these departments of knowledge, to the mutual advantage of both countries."

After the termination of the proceedings their Majesties inspected the new school. "They were accompanied by the Lord Mayor, Lord and Lady Curzon, Mr. H. A. L. Fisher, Sir John Hewett, Mr. P. J. Hartog, and Dr. Denison Ross, the director of the school.

\section{GEORGE MASSEE.}

M YCOLOGISTS in all parts of the world will learn with great regret of the death of Mr. G. Massee, which occurred at Sevenoaks, on February I7, after a brief illness. George Edward Massee was born at Scampston, in Yorkshire, about $185^{\circ}$, and at the age of ten was sent to school in York. He early showed a taste for drawing and natural history. At the York School of Art he gained the national medal for the year, and when about seventeen years old published a paper on woodpeckers in the Intellectual Observer. Later he studied botany under Spruce, a relative of his mother. It was intended that he should follow his. father's steps as a farmer, but, always ready for adventure, he readily accepted Spruce's suggestion to visit the West Indies and South America. He travelled in both the eastern and western countries of that continent, and, in addition to making botanical collections, sent home living plants in bulk.

On his return Massee's artistic talent became further manifest through the publication of his drawings in Spruce's "Hepaticæ Amazonicæ et Andinæ." He took up teaching and returned to the study of botany, specialising in fungi and plant diseases. He also got into touch with the late Dr. M. C. Cooke, and after working as a volunteer at Kew for some years he succeeded Cooke in 1893 as head of the Cruptogamic Department of the Herbarium, a post which he held until his retirement in I9I 5 .

Amongst his earlier volumes may be mentioned "British Fungi, Phycomycetes and Ustilagineæ" (189r), and "A Monograph of the Myxogastres" (1892). Between that year and 1895 four volumes of his "British Fungus Flora" were issued, the work remaining incomplete. The descriptions in this flora were detailed and comprehensive, and the book has proved indispensable to all British students.

Massee's serious pathological investigations began about 1895 , and from that date until his retirement a continuous stream of contributions to this subject flowed from his pen. His "Textbook of Plant Diseases" (1899), in which he made a wise selection from the best work of others, was a really good and useful book, and had perhaps a higher reputation than any other. Its publication marked a distinct epoch in the history of plant pathology in this country. In his larger work, "Diseases of Cultivated Plants and Trees" (I9ro), many of the author's own views, not always 
shared by others, are included. As a work of reference the later treatise is, however, unique and invaluable. In spite of his energies in the field of pathology, taxonomy still received attention, as is testified by the volumes, "European Agaricaceæ" (I902), "British Fungi and Lichens" (I9II), and "British Mildews, Rusts, and Smuts" (1913). Massee was a fellow of the Linnean Society from 1895 to 1915 . He was elected an associate in 1916 . In 1902 he received the Victoria Medal of Horticulture of the Royal Horticultural Society.

Massee's talent as a systematist lay perhaps mostly in his genius for recognising the affinities of a fungus and his remarkable memory. He wrote fluently and forcibly, and being full of energy and industry, was therefore an extremely rapid worker. His artistic powers were quite exceptional, and his drawings, many of which were extraordinarily beautiful, were usually executed with astonishing rapidity. His power of recalling the precise appearance of individual specimens was so great that he could with the greatest ease portray from memory a whole series of Agarics or other fungi. As to detail he was impatient, his style being always bold and vivid. Massee was a remarkable personality. Quick, shrewd, and outspoken, he was misunderstood by some. Those who knew him well understood and appreciated him, and mourn the loss of an old and valued friend.

A. D. C.

\section{THE PROMOTION OF TECHNICAL} OPTICS.

THE attention of all interested in the subject of technical optics, the importance of which we have emphasised repeatedly during the last few years, is directed to the subjoined valuable and interesting report, issued by the Board of Scientific Societies, having been approved by the Board on January 24. It will be recalled that the board was formed some time ago by the Royal Society after conferences with the learned and professional societies of the kingdom with the object of investigating scientific and technological problems arising out of the war. It is an additional testimony to the importance of the subject that this should be the first formal report issued by the board.

The committee upon whose labours the report is based was exceptionally well qualified to deal with its reference "to consider and report upon national instruction in technical optics." It comprised well-known representatives of the scientific, the industrial, and the educational aspects of optics, and included a high official of the Ministry of Munitions, which has had such good cause to realise thoroughly the disasters brought upon the nation by previous neglect.

The report is, we think advisedly at this stage, not overburdened with details, but deals with the matter in hand on broad lines, both as to the necessity for immediate action and the direction

$$
\text { NO. 2470, VOL. 99] }
$$

that action should take, but we are pleased to note that the "committee is willing," and, we assume, prepared, " to give further advice with respect to . . matters connected with subjects referred to in the report."

The necessity for immediate action is emphasised in weighty sentences, especially in regard to the numerous scientific and industrial interests involved. The report asserts that "the next few years are the years which will determine the future of the [optical] industries of the country."

The actual recommendations for action are directed towards concentration and appear to focus on two points - the provision of the "man" and of the "home" - though other matters of outstanding importance are not overlooked. The first point can be dealt with without any great delay by the appointment of a "director," as he is provisionally termed, whose initial duty will be the organisation and direction of the whole of the teaching, and who, assisted by a qualified staff, should, from the start, be able to advise "the trade in any difficulties they may encounter" until "a sufficient supply of men thoroughly trained" can be evolved. But such an appointment involves an appointing body, and this the board proposes to set up in the form of an independent "supervising representative council," which, although it is sometimes referred to as an "advisory council," obviously must have executive powers and the control of funds, and, presumably, would be a statutory body, although the report does not say so. It is strongly advocated that the council should be independent of any existing institution or governing body, as dependence would seem "to perpetuate what... should only be a transitional stage." Similarly, the director should not be a member of the staff or responsible to the governing body of any existing institution.

One of the dangers which the board appears to anticipate in too close a connection with, say, the Imperial College is the tendency to allocate all higher research to the favoured college. But higher research in any subject, and not least in such a subject as optics, grows naturally out of opportunities and predilections in any suitable soil, and it would be a mistake to endeavour to confine it to any one college or institution, especially if the favoured place has already many wider and diverse interests in other directions. The recent history of research in this very subject illustrates the point. We need only refer to what has been accomplished by Prof. H. Jackson at King's College, London, by the University of Sheffield, and by the Glass Research Committee of the Institute of Chemistry. Such researches are essentially strongly individualistic and not made to order, whilst, for the organised research involved in the investigation of particular industrial problems, there is the National Physical Laboratory created for this very purpose.

The other point referred to above-the provision of a "home"-is regarded by the board as of vital importance, and to be proceeded with "as soon as the preliminary work of organisation permits." 